\title{
PERANCANGAN APLIKASI PENJUALAN OBAT PERTANIAN PADA UD FAJAR TANI DENGAN METODE FORWARD CHAINING
}

\author{
Rikco David Saputra, Sri Lestanti, Dimas Fanny Hebrasianto Permadi \\ Program Studi Teknik Informatika S1, Fakultas Teknik Informasi \\ Universitas Islam Balitar, Blitar, Jl. Majapahit no 2 - 4 Sananwetan, Kota Blitar \\ rickodavid15@gmail.com
}

\begin{abstract}
ABSTRAK
UD Fajar Tani merupakan salah satu toko pertanian yang berada di desa pandanarum, Toko tersebut menjual berbagai jenis obat pertanian, Saat ini penjualan obat pertanian semakin meningkat dikarenakan hama dan penyakit pada tanaman yang sangat cepat penyebaran dan pertumbuhannya. Namun penjualan pada toko tersebut mengalami permasalahan pada proses pencarian obat yang sesuai dengan hama dan penyakit pada tanaman dikarenakan jenis obat yang sangat banyak. Berdasarkan permasalahan yang dihadapi oleh pemilik UD Fajar Tani maka dibutuhkan aplikasi yang bisa membantu dalam penjualan serta dapat menentukan hasil dari masalah yang ada untuk mengetahui jenis obat yang cocok untuk hama dan penyakit yang dialami. Pembuatan aplikasi tersebut menggunakan metode Forward Chaining. Hasil dari pemanfaatan metode tersebut dan berdasarkan pengujian menggunakan Black Box testing mendapatkan hasil nilai yang sangat baik yaitu sebesar 96.7\%. Dan 100\% untuk hasil dari pengujian validasi yang dilakukan oleh 8 sample. Sehingga dengan dibuatnya aplikasi tersebut dapat mempermudah dan membantu pemilik toko dalam mencari obat yang cocok dengan hama yang dialami pembeli.
\end{abstract}

Kata kunci : Hama, Forward Chaining, pengujian

\section{PENDAHULUAN}

Kemajuan teknologi dikala ini terus menjadi cepat. Dari tahun ke tahun teknologi serta komunikasi lalu bertumbuh, salah satunya merupakan internet. Internet ialah sesuatu alat data yang kilat serta cermat. Perihal ini membuat banyak warga yang menggunakan alat internet dalam bermacam berbagai kebutuhan, semacam dipakai buat kebutuhan bidang usaha. Mulai dari yang hendak membuat upaya sampai industri yang telah besar menggunakan perkembangan teknologi internet selaku alat yang berperan buat mengiklankan produk ataupun promosi. Tidak hanya dipakai buat alat advertensi serta pemasaran, internet pula bisa dipakai selaku alat pembelian produk serta data. sebab kemajuan teknologi serta data yang amat cepat, banyak zona kehidupan yang pasti buat dipakai. Salah satu wujud bidang usaha yang lagi jadi gaya terkini dikala ini merupakan pemasaran lewat web website dengan bermacam berbagai menu di dalamnya. Indonesia yang terdiri dari banyak pulau dengan masyarakat yang mendapatkan pemasukan selaku orang tani pasti ialah pangsa pasar yang besar [1].

Sektor pertanian merupakan salah satu faktor penting yang terdapat di negara Indonesia terlebih pada wilayah atau kota kecil seperti di Blitar, banyak warganya yang mayoritas ialah seorang petani. Untuk mendapatkan hasil panen yang maksimal petani membutuhkan pestisida atau obat-obatan untuk membantu menghilangkan hama dan menyuburkan tanaman. biasanya untuk satu musim petani membutuhkan lebih dari tiga jenis obat untuk tanamannya, hal ini berdampak pada para petani yang kurang mengetahui jenis jenis dan komposisi yang terdapat pada setiap obat yang dibeli, oleh karena itu biasanya petani salah memilih obat dan menjadi tidak maksimalnya hasil panen petani.

Bersumber pada informasi pemasaran pada UD Fajar Tani, $80 \%$ klien berawal dari dusun itu sendiri. Alhasil perihal itu menimbulkan capaian pemasaran pada UD Fajar Tani sedang terbatas pada wilayah sekelilingnya. Pemakaian sistem yang sedang konvensional pula menyebabkan klien yang ada di luar dusun ataupun kecamatan tidak bisa melaksanakan bisnis dengan gampang. Sering nya para konsumen menanyakan obat yang cocok untuk mengatasi hama yang mereka hadapi para karyawan yang sebenarnya bukan ahli di sektor pertanian kadang kebingungan untuk menjawab permasalahan tersebut dan mereka akan menelpon ataupun memanggil pemilik usaha untuk menanyakan obat tersebut, menjadikan banyak waktu yang terbuang untuk satu pelanggan yang bertanya.

Untuk membantu permasalahan yang terdapat pada UD Fajar Tani peneliti berasumsi dengan dibuatnya sistem pemasaran yang dijalani dengan cara online berplatform website. Dengan pembuatan sistem yang berplatform website hingga hendak mempermudah owner upaya dalam meningkatkan usahanya, dan gampang diakses oleh siapapun, serta kapanpun. Karyawan pun dapat menjawab pertanyaan para pelanggan tanpa memanggil dan bertanya pada Pemilik usaha, Dengan menggunakan metode Forward Chaining karyawan bisa mengetahui solusi yang tepat akan masalah dari para pelanggannya. Forward Chaining merupakan suatu metode yang dimana dapat menentukan suatu jenis obat berdasarkan permasalahan yang didapat. Hasil yang 
didapat yaitu memudahkan karyawan toko untuk menentukan jenis obat yang cocok untuk pelanggan dan menjadikan proses penjualan lebih mudah serta diakses kapan saja dan dimana saja. Sistem penjualan dengan menggunakan website mempermudah pembeli dalam memperoleh informasi tentang detail produk, harga produk dan dapat memudahkan dalam pengolahan manajemen data penjualan [1].

Peneliti memilih metode Forward Chaining dikarenakan peneliti ingin lebih membantu petani dalam mengatasi hama penyakitnya dan solusi obat yang harus dipakai oleh petani atas saran dari seorang pakar yang sudah lebih memahami di bidang pertanian. Tidak hanya dari faktor perangkingan yang belum tau atas dasar dari mana harus memilih obat tersebut, karena dalam sektor pertanian kesalahan penggunaan obat pestisida sangat fatal akibatnya bagi tanaman yang menerima obat tersebut bisa merusak tanaman dan lebih parahnya bisa mengakibatkan gagal panen oleh petani. Dari besarnya akibat yang ditimbulkan karena kesalahan obat maka peneliti lebih memilih Metode Forward Chaining dibandingkan metode lainya yang lebih mengutamakan perangkingan tanpa adanya pakar yang mengetahui lebih mendetail tentang pertanian di dalamnya.

\section{TINJAUAN PUSTAKA}

\subsection{Obat Atau Pestisida}

Pestisida ialah bahan kimia yang dipergunakan sebagai pembunuh hama, seperti insekta, jamur maupun gulma. Pestisida secara meluas dipergunakan sebagai pemberantas hama dan penyakit tanaman didalam bidang pertanian. Pestisida juga dipergunakan dirumah tangga sebagai pemberantas nyamuk, kecoa dan berbagai serangga pengganggu lainnya. [2]

\subsection{Metode Forward Chaining}

Forward Chaining ialah cara perunutan yang diawali dengan menunjukkan berkas informasi ataupun kenyataan yang memastikan mengarah konklusi akhir bias pula diucap selaku penalaran forward (forward Reasoning) ataupun pencarian yang dimotori informasi (data driven search). Pertamatama, sistem mencari seluruh ketentuan yang keadaannya ada diingatan kegiatan, setelah itu memilah salah satunya serta melaksanakan kelakuan yang berpadanan dengan ketentuan itu. Penentuan ketentuan yang hendak dijalani bersumber pada strategi senantiasa yang diucap strategi penyelesain bentrokan. Kelakuan itu menciptakan ingatan kegiatan terkini serta daur diulangi lagi hingga tidak terdapat ketentuan yang bisa dipicu, ataupun tujuan yang dikehendaki telah terkabul kamu bisa memandang di Bagan 2. 4 Ilustrasi ketentuan memakai forward chaining [3]
Tabel 1. Contoh rule forward chaining

\begin{tabular}{|l|l|}
\hline No & \multicolumn{1}{|c|}{ Aturan } \\
\hline R1 & IF A \& B THEN C \\
\hline R2 & IF C THEN D \\
\hline R3 & IF A \& E THEN F \\
\hline R4 & IF A THEN G \\
\hline R5 & IF F \& G THEN D \\
\hline R6 & IF G \& E THEN H \\
\hline R7 & IF C \& H THEN I \\
\hline R8 & IF I \& A THEN J \\
\hline R9 & IF G THEN J \\
\hline R10 & IF J THEN K \\
\hline
\end{tabular}

\subsection{Black Box Testing}

Black box testing ialah pengujian testing yang dilakukan pada perangkat lunak dengan tidak diketahui kinerja internalnya. Sehingga tester melihat perangkat lunak seperti halnya sebuah "kotak hitam" yang tidak penting dilihat isinya, tapi cukup dinilai proses testing di bagian luarnya [4]

\section{METODE PENELITIAN}

Penelitian ini mengambil alur dari metode pengembangan waterfall yang dimana alur dari penelitian ini bersifat turun seperti air terjun dari atas kebawah. Didalam penelitian ini peneliti membuat perbedaan dalam alur untuk penelitiannya dimana tidak seperti alur metode waterfall lainnya namun inti dari alurnya tetap sama yaitu turun dari atas ke bawah dan melalui proses yang sama seperti yang terdapat berdasarkan dari ilustrasi 1 dibawah ini.

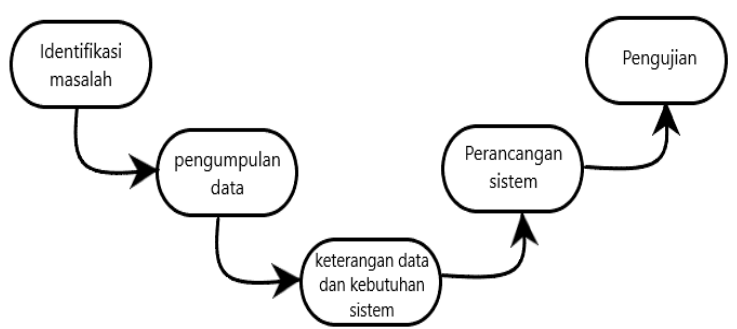

Gambar 1. Alur Penelitian

Gambar di atas dapat dijelaskan jika alur penelitian diawali dengan mengidentifikasi permasalahan, kemudian dilanjutkan dengan pengumpulan data. Setelah melakukan pengumpulan data, akan dilakukan analisa data dan kebutuhan sistem yang diperlukan, dilanjut dengan tahapan perancangan sistem dan pada tahapan terakhir akan dilakukan pengujian sistem, apakah sistem sudah dapat dijalankan dan sesuai dengan kebutuhan.

\subsection{Representasi Kebutuhan}

Dalam penelitian yang dilakukan peneliti tidak terlepas dari sebuah informasi yang diperlukan dari UD Fajar Tani. Karena dengan informasi tersebut dapat diketahui Nama obat, kegunaan obat, zat dalam obat dan harga obat tersebut serta aturan atau rule yang akan diberikan oleh pakar. Berikut data obat yang diambil peneliti dari UD Fajar Tani dan pakar: 
Tabel 2. Keterangan Data Obat

\begin{tabular}{|c|c|c|c|c|}
\hline No & Nama Obat & Untuk Tanaman Dan Hama & Bahan Aktiv & Harga \\
\hline 1 & $\begin{array}{c}\text { BESVIDOR } 25 \\
\text { WP }\end{array}$ & $\begin{array}{l}\text { Cabai : ulat grayak Spodoptera litura } \\
\text { Padi : walang sangit Leptocorisa oratorius. } \\
\text { Padi : wereng coklat Nilaparvata lugens, penggerek batang } \\
\text { Scirpophaga incertulas / ngengat putih. }\end{array}$ & imidakloprid : $25 \%$ & $\operatorname{Rp} 25.000$ \\
\hline 2 & $\begin{array}{c}\text { CONFIDOR } 5 \\
\text { WP }\end{array}$ & $\begin{array}{l}\text { Cabai : kutu daun Myzus persicae, hama trips Thrips parvispinus } \\
\text { Padi sawah : walang sangit Leptocorisa acuta. } \\
\text { Padi sawah : kepik hitam ramping Pachybarachlus pallicornis. } \\
\text { Padi sawah: wereng coklat Nilaparvata lugens. }\end{array}$ & $\begin{array}{l}\text { imidakloprid } \\
\text { (imidacloprid) : } 5 \%\end{array}$ & Rp 33.000 \\
\hline 3 & $\begin{array}{c}\text { ANTRACOL } 70 \\
\text { WP }\end{array}$ & $\begin{array}{l}\text { Padi sawah : penyakit bercak daun Cercospora sp., penyakit busuk } \\
\text { pelepah Rhizoctonia solani, penyakit bercak coklat Cercospora } \\
\text { janseana } \\
\text { Cabai merah : penyakit bercak daun Cercospora sp. }\end{array}$ & propineb : $70 \%$ & $\operatorname{Rp} 34.000$ \\
\hline 4 & SAMAR 75 WP & $\begin{array}{l}\text { Bawang merah: penyakit bercak ungu Alternaria porri } \\
\text { Padi : penyakit blast Pyricularia oryzae / Penyakit Blas disebabkan } \\
\text { oleh meluasnya serangan jamur Pyricularia oryzae }\end{array}$ & trisiklazol : $75 \%$ & Rp 50.000 \\
\hline 5 & SUMO 50 EC & Cabai : ulat grayak Spodoptera litura / ulat hijau & $\begin{array}{l}\text { beta siflutrin (beta } \\
\text { cyfluthrin) : } 50 \mathrm{~g} / 1\end{array}$ & Rp 55.000 \\
\hline 6 & $\begin{array}{c}\text { STARBAN } 585 \\
\text { EC }\end{array}$ & $\begin{array}{l}\text { Bawang merah : ulat grayak Spodoptera exigua } \\
\text { Jagung : penggerek batang Ostrinia nubilalis } \\
\text { Kedelai : penggerek polong Etiella zinckenella }\end{array}$ & $\begin{array}{l}\text { klorpirifos } \\
\text { (chlorpyrifos) : } 530 \mathrm{~g} / 1 \\
\text { sipermetrin } \\
\text { (cypermethrin) : } 55 \mathrm{~g} / 1\end{array}$ & $\operatorname{Rp} 26.000$ \\
\hline 7 & $\begin{array}{l}\text { RAMBO PEAK } \\
550 \text { SL }\end{array}$ & Untuk membunuh tanaman liar (gulma) & $\begin{array}{l}\text { isopropil amina } \\
\text { glifosat (setara denga } \\
\text { glifosat: } 408 \mathrm{~g} / \mathrm{l}): 550 \\
\mathrm{~g} / 1\end{array}$ & $\operatorname{Rp} 63.000$ \\
\hline 8 & $\begin{array}{l}\text { NOXONE } 297 \\
\text { SL }\end{array}$ & $\begin{array}{l}\text { Padi sawah (TOT) : gulma berdaun lebar Alternanthera sessilis, } \\
\text { Ludwigia octovalvis, Monochoria vaginalis, gulma berdaun sempit, } \\
\text { Echinochloa crus-galli, teki Cyperus iria } \\
\text { Tebu : gulma berdaun lebar Ageratum conyzoides, Borreria alata, } \\
\text { Jagung : gulma berdaun lebar Ageratum conyzoides, synedrella } \\
\text { nodiflora, }\end{array}$ & $\begin{array}{l}\text { parakuat diklorida } \\
\text { (setara dengan ion } \\
\text { parakuat: } 215 \mathrm{~g} / \mathrm{l} \text { ) : } \\
297 \mathrm{~g} / \mathrm{l}\end{array}$ & $\operatorname{Rp} 65.000$ \\
\hline 9 & $\begin{array}{l}\text { KCL Cap } \\
\text { Bintang }\end{array}$ & $\begin{array}{l}\text { pupuk yang berguna untuk meningkatkan hasil tanaman melalui } \\
\text { fungsinya yang mampu membantu pertumbuhan organ-organ generatif } \\
\text { seperti biji, buah, dan bunga. (untuk menyuburkan tanaman) }\end{array}$ & $\begin{array}{l}\text { Kalium } 40 \% \\
\text { Mn } 2.40 \% \\
\mathrm{Zn} 3.02 \% \\
\mathrm{Mg} 2.25 \% \\
\mathrm{Cu} 2.05 \% \\
\text { B } 2.02 \% \\
\text { Unsur lain } 48 \%\end{array}$ & $\operatorname{Rp} 25.000$ \\
\hline 10 & $\begin{array}{l}\text { TRISULA } 450 \\
\text { SL }\end{array}$ & $\begin{array}{l}\text { Padi : wereng coklat Nilaparvata lugens } \\
\text { Padi : penggerek batang Scirpophaga sp. }\end{array}$ & monosultap : $450 \mathrm{~g} / 1$ & $\operatorname{Rp} 25.000$ \\
\hline 11 & $\begin{array}{c}\text { EXPLORE } 250 \\
\text { EC }\end{array}$ & $\begin{array}{l}\text { Cabai : penyakit bercak daun Cercospora capsica } \\
\text { Jagung : penyakit bulai Peronosclerospora maydis, penyakit hawar } \\
\text { daun Helminthosporium turcicum } \\
\text { Padi : penyakit blas Pyricularia oryzae, penyakit hawar daun } \\
\text { Rhizoctonia solani }\end{array}$ & $\begin{array}{l}\text { difenokonazol } \\
\text { (difenoconazole) }: 250 \\
\text { g/1 }\end{array}$ & Rp 120.000 \\
\hline 12 & SEVIN 85 SP & $\begin{array}{l}\text { Semua tanaman : hama perusak daun Plusia chalcites, hama penghisap } \\
\text { buah Helopeltis antonii, ulat api Setora nitens, kutu putih Planococcus } \\
\text { citri, penghisap buah Dasynus piperis, ulat grayak Spodoptera litura }\end{array}$ & $\begin{array}{l}\text { karbaril (carbaryl) : } 85 \\
\%\end{array}$ & $\operatorname{Rp} 25.000$ \\
\hline 13 & $\begin{array}{l}\text { SIDAMETHRIN } \\
50 \mathrm{EC}\end{array}$ & Jagung : belalang Patanga succincta & $\begin{array}{l}\text { sipermetrin } \\
\text { (cypermethrin) }: 50 \mathrm{~g} / 1\end{array}$ & $\operatorname{Rp} 35.000$ \\
\hline 14 & $\begin{array}{c}\text { WIN GREAT } \\
400 \mathrm{EC}\end{array}$ & Padi dan jagung : Penggerek batang, wereng coklat & $\begin{array}{l}\text { Imidakloprid } 100 \mathrm{~g} / \mathrm{L} \\
+ \text { BPMC } 300 \mathrm{~g} / \mathrm{L}\end{array}$ & $\operatorname{Rp} 35.000$ \\
\hline 15 & REGENT $50 \mathrm{SC}$ & $\begin{array}{l}\text { Cabai : hama thrips Thrips parvispinus, kutu daun Myzus persicae } \\
\text { Jagung : belalang Locusta sp. } \\
\text { Jagung : semut Solenopsis germinate } \\
\text { padi : walang sangit Leptocorisa oratorius, wereng coklat Nilaparvata } \\
\text { lugens, penggerek batang Tryporiza innotata } \\
\text { Padi : hama orong-orong Gryllotalpa sp. }\end{array}$ & fipronil : $50 \mathrm{~g} / 1$ & $\operatorname{Rp} 35.000$ \\
\hline 16 & $\begin{array}{l}\text { MASALGIN } 50 \\
\text { WP }\end{array}$ & $\begin{array}{l}\text { Cabai merah : penyakit antraknosa buah Colletotrichum capsici, } \\
\text { penyakit bercak daun Cercospora capsici }\end{array}$ & $\begin{array}{l}\text { benomil (benomyl) : } \\
50 \%\end{array}$ & $\operatorname{Rp} 30.000$ \\
\hline 17 & $\begin{array}{l}\text { PANDAWA } 60 \\
\text { WP }\end{array}$ & $\begin{array}{l}\text { padi : penggerek batang kuning Scircophaga incertulas, wereng batang } \\
\text { coklat Nilaparvata lugens }\end{array}$ & $\begin{array}{l}\text { Tiamctoksam } 10 \% \text {, } \\
\text { Bisultap 50\% }\end{array}$ & $\operatorname{Rp} 35.000$ \\
\hline 18 & $\begin{array}{l}\text { DUPONT } \\
\text { LANNATE } 40 \\
\text { SP }\end{array}$ & cabai : ulat grayak Spodoptera litura & metomil $40 \%$ & $\operatorname{Rp} 40.000$ \\
\hline 19 & $\begin{array}{l}\text { NORDOX } 56 \\
\text { WP }\end{array}$ & $\begin{array}{l}\text { Jagung : penyakit bulai Peronosclerospora maydis } \\
\text { Padi : penyakit blas Pyricularia oryzae } \\
\text { Padi : penyakit hawar daun Xanthomonas oryzae } \\
\text { Padi : penyakit bakteri daun bergores Xanthomonas oryzae } \\
\text { Padi gogo : penyakit hawar daun bakteri Xanthomonas campestris }\end{array}$ & $\begin{array}{l}\text { setara dengan tembaga } \\
\text { (copper active } \\
\text { equivalent) }: 50 \% \\
\text { tembaga oksida } \\
\text { (copper oxide) }: 56 \%\end{array}$ & $\operatorname{Rp} 25.000$ \\
\hline 20 & KLOPINDO 10 & Cabai : kutu daun myzus persicae & Imidakloprid $10 \%$ & Rp 20.000 \\
\hline
\end{tabular}




\begin{tabular}{|c|c|c|c|c|}
\hline No & Nama Obat & Untuk Tanaman Dan Hama & Bahan Aktiv & Harga \\
\hline & WP & $\begin{array}{l}\text { Padi : wareng coklat nilaparvata lugens } \\
\text { Padi: walang sangit leptocorisa sp }\end{array}$ & & \\
\hline 21 & $\begin{array}{l}\text { METINDO } 40 \\
\text { SP }\end{array}$ & $\begin{array}{l}\text { Cabai dan padi : Ulat Grayak, Penggerek Buah, Penggerek pucuk, dan } \\
\text { perusak daun. }\end{array}$ & metomil : $40 \%$ & Rp 10.000 \\
\hline 22 & $\begin{array}{l}\text { EXPLORE } 250 \\
\text { EC }\end{array}$ & $\begin{array}{l}\text { Jagung : penyakit bulai Peronosclerospora maydis, penyakit hawar } \\
\text { daun Helminthosporium turcicum } \\
\text { Padi : penyakit blas Pyricularia oryzae } \\
\text { Padi : penyakit hawar daun Rhizoctonia solani }\end{array}$ & $\begin{array}{l}\text { difenokonazol } \\
\text { (difenoconazole) }: 250 \\
\mathrm{~g} / \mathrm{l}\end{array}$ & Rp 120.000 \\
\hline 23 & TRIVIA 73 WP & $\begin{array}{l}\text { Jagung : penyakit bulai Peronosclerospora maydis, penyakit hawar } \\
\text { daun Helminthosporium turcicum } \\
\text { Padi : penyakit bercak coklat Cercospora janseana, penyakit blas } \\
\text { Pyricularia oryzae, penyakit hawar pelepah Rhizoctonia solani, } \\
\text { penyakit hawar daun Xanthomonas oryzae, penyakit bercak bulir } \\
\text { gabah Cercospora janseana }\end{array}$ & $\begin{array}{l}\text { fluopikolid : } 6 \% \\
\text { propineb : } 67 \%\end{array}$ & $\operatorname{Rp} 30.000$ \\
\hline 24 & $\begin{array}{l}\text { TOPSIN-M } 70 \\
\text { WP }\end{array}$ & $\begin{array}{l}\text { Cabai : Penyakit antraknosa buah (Gleosporium sp) } \\
\text { Cabai : Penyakit bercak daun (Cercospora spp) } \\
\text { Padi : Penyakit bias (Piricularia oryzae) }\end{array}$ & Metil tiofanat $70 \%$ & $\operatorname{Rp} 25.000$ \\
\hline 25 & $\begin{array}{l}\text { GARDARA } 10 \\
\text { SP }\end{array}$ & Padi : wereng, walang sangit, thrips, kutu perisai, kutu kebul & Nitenpiram $10 \%$ & $\operatorname{Rp} 38.000$ \\
\hline 26 & $\begin{array}{l}\text { APPLAUD } 10 \\
\text { WP }\end{array}$ & $\begin{array}{l}\text { Cabai merah : tungau teh kuning Polyphagotarsonemus latus } \\
\text { Padi : wereng coklat Nilaparvata lugens } \\
\text { Padi : wereng hijau Nephotettix sp. }\end{array}$ & buprofezin : $10 \%$ & $\operatorname{Rp} 20.000$ \\
\hline 27 & $\begin{array}{l}\text { MIPCINTA } 50 \\
\text { WP }\end{array}$ & $\begin{array}{l}\text { Jagung : belalang Locusta sp. } \\
\text { Padi: Hama putih palsu Cnaphalocrosis medinalis } \\
\text { Padi: wereng hijau Nephotetix virescens } \\
\text { Padi: wereng coklat Nilaparvata lugens walang sangit Leptocorisa } \\
\text { oratorius }\end{array}$ & MIPC : $50 \%$ & Rp 16.000 \\
\hline 28 & $\begin{array}{l}\text { BENFURON } \\
12 / 18 \mathrm{WP}\end{array}$ & $\begin{array}{l}\text { Padi sawah : gulma berdaun lebar Ludwigia octovalvis, Monochoria } \\
\text { vaginalis, Limnocharis flava, Sphenochloa zeylanica, teki Fimbristylis } \\
\text { miliacea }\end{array}$ & $\begin{array}{l}\text { metil bensulfuron : } 12 \\
\% \\
\text { sodium bispiribak : } 18 \\
\%\end{array}$ & Rp 15.000 \\
\hline 29 & $\begin{array}{l}\text { ACROBAT } 50 \\
\text { WP }\end{array}$ & $\begin{array}{l}\text { Cabai : bercak daun } \\
\text { Jagung : bulai }\end{array}$ & Dimetomorf $50 \%$ & $\operatorname{Rp} 30.000$ \\
\hline 30 & $\begin{array}{l}\text { SAROMYL } 35 \\
\text { SD }\end{array}$ & Perlakuan benih jagung: penyakit bulai Peronosclerospora maydis & metalaksil : $35 \%$ & Rp 8.000 \\
\hline 31 & RECOR 250 EC & $\begin{array}{l}\text { padi : penyakit hawar pelepah Rhizoctonia sp. } \\
\text { padi : penyakit busuk batang Helminthosporium sigmoideum }\end{array}$ & $\begin{array}{l}\text { difenokonazol : } 250 \\
\mathrm{~g} / \mathrm{l}\end{array}$ & $\operatorname{Rp} 90.000$ \\
\hline 32 & FILIA 525 SE & Padi : penyakit blas jamur Pyriculae oryzae & $\begin{array}{l}\text { Propokanazol } 125 \mathrm{~g} / \mathrm{l}, \\
\text { Trisiklazol } 400 \mathrm{~g} / \mathrm{l}\end{array}$ & Rp 125.000 \\
\hline 33 & CRONUS $18 \mathrm{EC}$ & $\begin{array}{l}\text { Cabai merah : hama thrips Thrips parvispinus, hama kutu daun Myzus } \\
\text { persicae }\end{array}$ & $\begin{array}{l}\text { abamektin (abamectin) } \\
: 18 \mathrm{~g} / 1\end{array}$ & Rp 85.000 \\
\hline
\end{tabular}

Tabel 3. Data Kode Hama

\begin{tabular}{|l|l|}
\hline Kode Hama & \multicolumn{1}{|c|}{ Jenis Hama / Penyakit } \\
\hline H01 & Ulat Grayak Spodoptera Litura / Ulat Hijau \\
\hline H02 & Walang Sangit Leptocorisa Oratorius \\
\hline H03 & Penyakit Bercak Daun Cercospora Sp (jamur daun) \\
\hline H04 & Serangan Jamur Pyricularia Oryzae \\
\hline H05 & Gulma Berdaun Lebar Alternanthera Sessilis \\
\hline H06 & Wereng Coklat Nilaparvata Lugens \\
\hline H07 & Penggerek batang scirpophaga sp (hewan ngengat) \\
\hline H08 & Kutu Daun Myzus Persicae, Hama Trips Thrips Parvispinus \\
\hline H09 & Kepik Hitam Ramping Pachybarachlus Pallicornis \\
\hline H10 & Busuk Pelepah Pada Tanaman \\
\hline H11 & Belalang Patanga Succincta \\
\hline H12 & Penggerek Batang Tryporiza Innotata \\
\hline H13 & Hama Orong-Orong Gryllotalpa Sp \\
\hline H14 & Semut Solenopsis Germinate \\
\hline H15 & Penyakit Bulai Peronosclerospora Maydis \\
\hline H16 & Penyakit Hawar Daun Xanthomonas Oryzae \\
\hline H17 & Penyakit Bakteri Daun Bergores Xanthomonas Oryzae \\
\hline H18 & Penggerek Buah \\
\hline H19 & Penyakit Hawar Daun Rhizoctonia Solani \\
\hline H20 & Penyakit Hawar Daun Helminthosporium Turcicum (Jagung) \\
\hline H21 & Wereng Hijau Nephotettix Sp. \\
\hline H22 & Penyakit Antraknosa Buah \\
\hline
\end{tabular}


Setelah memiliki data obat dari tempat studi kasus atau UD Fajar Tani, maka dapat diketahui code obat serta code hama dan penyakitnya setelah semua tersusun maka didapat rule dari pakar yang bisa diketahui pada tabel di bawah.

Tabel 4. Data Aturan Atau Rule

\begin{tabular}{|c|c|}
\hline Aturan (Rule) & Pemilihan Obat (END) \\
\hline R1 & IF H01 OR H02 OR H06 THEN K01 \\
\hline R2 & IF H03 THEN K02 \\
\hline R3 & IF H04 THEN K03 \\
\hline R4 & IF H05 THEN K04 \\
\hline R5 & IF H02 OR H06 OR H08 OR H09 THEN K05 \\
\hline R6 & IF H11 THEN K07 \\
\hline R7 & IF H03 OR H22 THEN K09 \\
\hline R8 & IF H01 THEN K10 \\
\hline R9 & IF H04 OR H15 OR H16 OR H17 THEN K11 \\
\hline R10 & IF H02 OR H06 OR H08 THEN K12 \\
\hline R11 & IF H01 OR H18 THEN K13 \\
\hline R12 & IF H03 OR H04 OR H15 OR H20 THEN K15 \\
\hline R13 & IF H22 THEN K16 \\
\hline R14 & IF H03 OR H04 OR H10 OR H19 OR H20 OR H15 THEN K14 \\
\hline R15 & IF H02 OR H08 THEN K17 \\
\hline R16 & IF H06 OR H21 THEN K18 \\
\hline R17 & IF H03 OR H15 THEN K20 \\
\hline R18 & IF H15 THEN K21 \\
\hline R19 & IF H10 OR H19 THEN K22 \\
\hline R20 & IF H08 THEN K23 \\
\hline R21 &
\end{tabular}

\subsection{Perancangan DFD dan Flowchart}

DFD level 0, ialah penjelasan dari diagram konteks, bisa dilihat berdasarkan dari ilustrasi 2 di atas dapat dijelaskan bahwa admin dapat menambah data atau obat tersebut serta mengetahui stok data atau obat tersebut sedangkan User dapat menginputkan jenis hama serta memilih obat tersebut dan membeli obat.

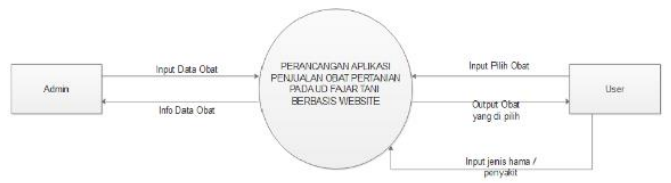

Gambar 2. DFD level 0

Flowchart ialah bagan yang menjelaskan dengan rinci tahapan-tahapan dari proses program seperti berdasarkan ilustrasi 3 di atas dan Dapat dijelaskan bahwa Flowchart sistem dimulai dari pembeli / user memilih menu yaitu ingin memakai forward chaining atau langsung mencari obat yang diinginkan jika memilih ingin memakai forward chaining selanjutnya user memilih hama apa yang di alami di tanamannya setelah itu sistem akan memprosesnya dengan metode forward chaining selanjutnya akan muncul obat yang dicari berdasarkan hama yang dipilih sebelumnya selanjutnya pilih obat dan jika user tidak ingin memakai forward chaining maka user langsung memilih obat yang diinginkan dan langsung pilih obat, lalu sistem mengkonfrimasi obat tersebut apakah tersedia atau tidak jika tersedia user / pembeli akan lanjut ke pembelian obat menyelesaikan pembayaran dan selesai, tetapi jika dikonfirmasi obat tidak tersedia maka user / pembeli diarahkan kembali ke pemilihan obat.

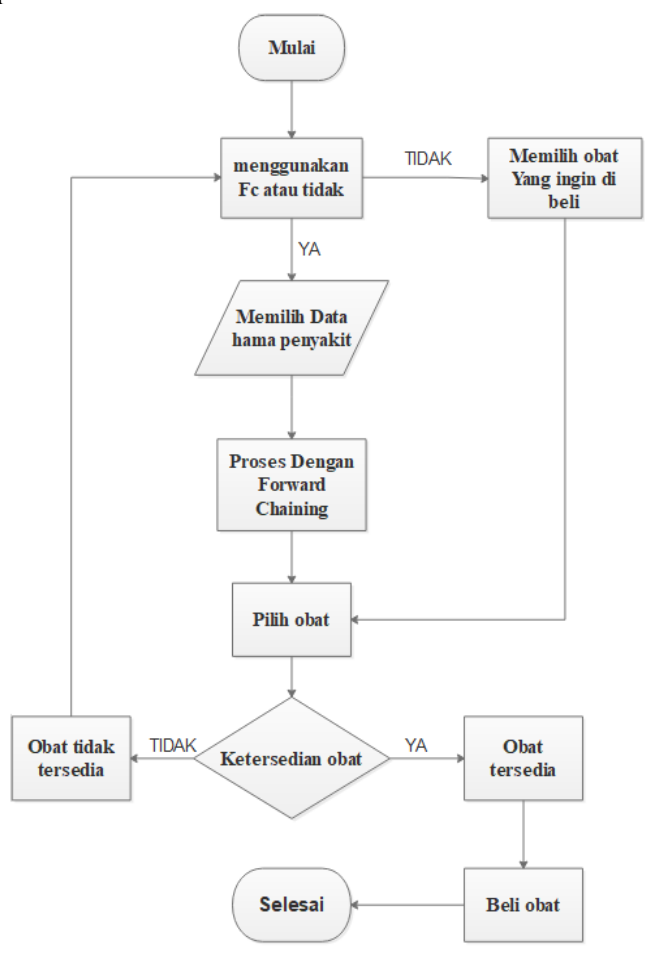

Gambar 3. Flowchart sistem 


\section{HASIL DAN PEMBAHASAN}

Hasil dari pengujian yang dilakukan dengan black box testing dan validisi pada sistem penjualan obat pertanian pada Ud Fajar Tani serta sistem pakar yang memakai metode forward chaining menunjukkan bahwa kinerja sistem sudah berjalan dengan baik. Dari pengujian black box testing dengan jumlah sebanyak 31 pengujian fungsional mendapatkan hasil presentase sebesar $96,7 \%$ dengan jumlah kegagalan pengujian sistem sebanyak 1 kegagalan

\subsection{Uji Validasi}

Tabel 5. Uji Validasi

\begin{tabular}{|c|c|c|c|c|c|c|c|c|c|c|c|c|c|c|c|c|c|c|c|c|}
\hline \multirow{2}{*}{ No } & \multicolumn{9}{|c|}{ Rule } & \multirow{2}{*}{$\begin{array}{c}\text { Output } \\
\text { sistem }\end{array}$} & \multirow{2}{*}{$\begin{array}{c}\text { Hasil } \\
\text { Dari } \\
\text { Pakar }\end{array}$} & \multicolumn{9}{|c|}{ Hasil Dari Sample } \\
\hline & & & & & & & & & & & & 1 & 2 & 3 & 4 & 5 & 6 & 7 & 8 & 9 \\
\hline 1 & H01 & H02 & $\mathrm{H} 03$ & $\mathrm{H} 04$ & H05 & H06 & H07 & $\mathrm{H} 08$ & H09 & K01 & Valid & $\sqrt{ }$ & $\sqrt{ }$ & $\sqrt{ }$ & $\sqrt{ }$ & $\sqrt{ }$ & $\sqrt{ }$ & $\sqrt{ }$ & $\sqrt{ }$ & $\sqrt{ }$ \\
\hline 2 & $\mathrm{H} 01$ & $\mathrm{HO2}$ & $\mathrm{H} 03$ & H04 & H05 & H06 & H07 & $\mathrm{H} 08$ & H09 & K02 & Valid & $\sqrt{ }$ & $\sqrt{ }$ & $\sqrt{ }$ & $\sqrt{ }$ & $\sqrt{ }$ & $\sqrt{ }$ & $\sqrt{ }$ & $\sqrt{ }$ & $\sqrt{ }$ \\
\hline 3 & H01 & $\mathrm{H} 02$ & $\mathrm{H} 03$ & H04 & $\mathrm{H} 05$ & H06 & H07 & $\mathrm{H} 08$ & H09 & K03 & Valid & $\sqrt{ }$ & $\sqrt{ }$ & $\sqrt{ }$ & $\sqrt{ }$ & $\sqrt{ }$ & $\sqrt{ }$ & $\sqrt{ }$ & $\sqrt{ }$ & $\sqrt{ }$ \\
\hline 4 & $\mathrm{H} 01$ & $\mathrm{H} 02$ & $\mathrm{H} 03$ & $\mathrm{H} 04$ & H05 & $\mathrm{H} 06$ & $\mathrm{H} 07$ & $\mathrm{H} 08$ & $\mathrm{H} 09$ & K04 & Valid & $\sqrt{ }$ & $\sqrt{ }$ & $\sqrt{ }$ & $\sqrt{ }$ & $\sqrt{ }$ & $\sqrt{ }$ & $\sqrt{ }$ & $\sqrt{ }$ & $\sqrt{ }$ \\
\hline 5 & H01 & H02 & $\mathrm{H} 03$ & H04 & H05 & H06 & H07 & H08 & H09 & K05 & Valid & $\sqrt{ }$ & $\sqrt{ }$ & $\sqrt{ }$ & $\sqrt{ }$ & $\sqrt{ }$ & $\sqrt{ }$ & $\sqrt{ }$ & $\sqrt{ }$ & $\sqrt{ }$ \\
\hline 6 & H01 & H02 & $\mathrm{H} 03$ & $\mathrm{H} 04$ & $\mathrm{H} 05$ & H06 & H07 & $\mathrm{H} 08$ & H09 & K06 & Valid & $\sqrt{ }$ & $\sqrt{ }$ & $\sqrt{ }$ & $\sqrt{ }$ & $\sqrt{ }$ & $\sqrt{ }$ & $\sqrt{ }$ & $\sqrt{ }$ & $\sqrt{ }$ \\
\hline 7 & $\mathrm{H} 01$ & $\mathrm{HO2}$ & $\mathrm{H} 03$ & $\mathrm{HO4}$ & H07 & H09 & $\mathrm{H} 10$ & H11 & $\mathrm{H} 12$ & K07 & Valid & $\sqrt{ }$ & $\sqrt{ }$ & $\sqrt{ }$ & $\sqrt{ }$ & $\sqrt{ }$ & $\sqrt{ }$ & $\sqrt{ }$ & $\sqrt{ }$ & $\sqrt{ }$ \\
\hline 8 & H02 & $\mathrm{H} 03$ & H06 & H08 & H09 & H12 & $\mathrm{H} 13$ & H14 & H15 & K08 & Valid & $\sqrt{ }$ & $\sqrt{ }$ & $\sqrt{ }$ & $\sqrt{ }$ & $\sqrt{ }$ & $\sqrt{ }$ & $\sqrt{ }$ & $\sqrt{ }$ & $\sqrt{ }$ \\
\hline 9 & $\mathrm{H} 01$ & $\mathrm{H} 02$ & $\mathrm{H} 03$ & H07 & H16 & $\mathrm{H} 17$ & $\mathrm{H} 18$ & H19 & $\mathrm{H} 22$ & K09 & Valid & $\sqrt{ }$ & $\sqrt{ }$ & $\sqrt{ }$ & $\sqrt{ }$ & $\sqrt{ }$ & $\sqrt{ }$ & $\sqrt{ }$ & $\sqrt{ }$ & $\sqrt{ }$ \\
\hline 10 & H01 & H02 & $\mathrm{H} 03$ & H04 & H05 & H06 & H07 & H08 & H09 & K10 & Valid & $\sqrt{ }$ & $\sqrt{ }$ & $\sqrt{ }$ & $\sqrt{ }$ & $\sqrt{ }$ & $\sqrt{ }$ & $\sqrt{ }$ & $\sqrt{ }$ & $\sqrt{ }$ \\
\hline 11 & $\mathrm{H} 03$ & H04 & $\mathrm{H} 05$ & $\mathrm{H} 10$ & H11 & H15 & H16 & H17 & H18 & K11 & Valid & $\sqrt{ }$ & $\sqrt{ }$ & $\sqrt{ }$ & $\sqrt{ }$ & $\sqrt{ }$ & $\sqrt{ }$ & $\sqrt{ }$ & $\sqrt{ }$ & $\sqrt{ }$ \\
\hline 12 & $\mathrm{H} 01$ & $\mathrm{H} 02$ & $\mathrm{H} 03$ & $\mathrm{H} 04$ & $\mathrm{H} 05$ & H06 & $\mathrm{H} 07$ & $\mathrm{H} 08$ & $\mathrm{H} 09$ & K12 & Valid & $\sqrt{ }$ & $\sqrt{ }$ & $\sqrt{ }$ & $\sqrt{ }$ & $\sqrt{ }$ & $\sqrt{ }$ & $\sqrt{ }$ & $\sqrt{ }$ & $\sqrt{ }$ \\
\hline 13 & H01 & H02 & $\mathrm{H} 03$ & H10 & H11 & H18 & H19 & $\mathrm{H} 20$ & $\mathrm{H} 21$ & K13 & Valid & $\sqrt{ }$ & $\sqrt{ }$ & $\sqrt{ }$ & $\sqrt{ }$ & $\sqrt{ }$ & $\sqrt{ }$ & $\sqrt{ }$ & $\sqrt{ }$ & $\sqrt{ }$ \\
\hline 14 & $\mathrm{H} 02$ & $\mathrm{H} 03$ & H04 & H09 & $\mathrm{H} 10$ & $\mathrm{H} 14$ & H15 & H19 & $\mathrm{H} 20$ & K14 & Valid & $\sqrt{ }$ & $\sqrt{ }$ & $\sqrt{ }$ & $\sqrt{ }$ & $\sqrt{ }$ & $\sqrt{ }$ & $\sqrt{ }$ & $\sqrt{ }$ & $\sqrt{ }$ \\
\hline 15 & H03 & H04 & $\mathrm{H} 05$ & H14 & H15 & H16 & H17 & H18 & $\mathrm{H} 20$ & K15 & Valid & $\sqrt{ }$ & $\sqrt{ }$ & $\sqrt{ }$ & $\sqrt{ }$ & $\sqrt{ }$ & $\sqrt{ }$ & $\sqrt{ }$ & $\sqrt{ }$ & $\sqrt{ }$ \\
\hline 16 & $\mathrm{H} 01$ & $\mathrm{H} 02$ & $\mathrm{H} 03$ & $\mathrm{H} 10$ & $\mathrm{H} 15$ & H19 & $\mathrm{H} 20$ & $\mathrm{H} 21$ & $\mathrm{H} 22$ & K16 & Valid & $\sqrt{ }$ & $\sqrt{ }$ & $\sqrt{ }$ & $\sqrt{ }$ & $\sqrt{ }$ & $\sqrt{ }$ & $\sqrt{ }$ & $\sqrt{ }$ & $\sqrt{ }$ \\
\hline 17 & H01 & H02 & $\mathrm{H} 03$ & H04 & H05 & H06 & H07 & H08 & H09 & K17 & Valid & $\sqrt{ }$ & $\sqrt{ }$ & $\sqrt{ }$ & $\sqrt{ }$ & $\sqrt{ }$ & $\sqrt{ }$ & $\sqrt{ }$ & $\sqrt{ }$ & $\sqrt{ }$ \\
\hline 18 & $\mathrm{H} 03$ & H04 & H05 & H06 & H18 & H19 & $\mathrm{H} 20$ & $\mathrm{H} 21$ & H22 & K18 & Valid & $\sqrt{ }$ & $\sqrt{ }$ & $\sqrt{ }$ & $\sqrt{ }$ & $\sqrt{ }$ & $\sqrt{ }$ & $\sqrt{ }$ & $\sqrt{ }$ & $\sqrt{ }$ \\
\hline 19 & $\mathrm{H} 01$ & $\mathrm{H} 02$ & $\mathrm{H} 05$ & H06 & $\mathrm{H} 10$ & H11 & H19 & $\mathrm{H} 20$ & $\mathrm{H} 21$ & K19 & Valid & $\sqrt{ }$ & $\sqrt{ }$ & $\sqrt{ }$ & $\sqrt{ }$ & $\sqrt{ }$ & $\sqrt{ }$ & $\sqrt{ }$ & $\sqrt{ }$ & $\sqrt{ }$ \\
\hline 20 & $\mathrm{H} 01$ & $\mathrm{H} 02$ & $\mathrm{H} 03$ & $\mathrm{H} 04$ & $\mathrm{H} 10$ & $\mathrm{H} 13$ & $\mathrm{H} 14$ & $\mathrm{H} 15$ & H16 & K20 & Valid & $\sqrt{ }$ & $\sqrt{ }$ & $\sqrt{ }$ & $\sqrt{ }$ & $\sqrt{ }$ & $\sqrt{ }$ & $\sqrt{ }$ & $\sqrt{ }$ & $\sqrt{ }$ \\
\hline 21 & $\mathrm{H} 10$ & H11 & $\mathrm{H} 12$ & $\mathrm{H} 13$ & H14 & H15 & H16 & H17 & H18 & K21 & Valid & $\sqrt{ }$ & $\sqrt{ }$ & $\sqrt{ }$ & $\sqrt{ }$ & $\sqrt{ }$ & $\sqrt{ }$ & $\sqrt{ }$ & $\sqrt{ }$ & $\sqrt{ }$ \\
\hline 22 & H10 & H11 & $\mathrm{H} 12$ & $\mathrm{H} 15$ & H16 & H17 & $\mathrm{H} 18$ & H19 & $\mathrm{H} 20$ & K22 & Valid & $\sqrt{ }$ & $\sqrt{ }$ & $\sqrt{ }$ & $\sqrt{ }$ & $\sqrt{ }$ & $\sqrt{ }$ & $\sqrt{ }$ & $\sqrt{ }$ & $\sqrt{ }$ \\
\hline 23 & $\mathrm{H} 05$ & $\mathrm{H} 06$ & $\mathrm{H} 07$ & H08 & H09 & $\mathrm{H} 10$ & H11 & $\mathrm{H} 12$ & $\mathrm{H} 13$ & K23 & Valid & $\sqrt{ }$ & $\sqrt{ }$ & $\sqrt{ }$ & $\sqrt{ }$ & $\sqrt{ }$ & $\sqrt{ }$ & $\sqrt{ }$ & $\sqrt{ }$ & $\sqrt{ }$ \\
\hline
\end{tabular}

\section{$\begin{array}{lllll}\text { Keterangan } & \text { Tidak } & \text { Ya } & \sqrt{ } & \text { Valid }\end{array}$}

Dari semua Rule yang telah di validasi atau diuji maka dapat di ketahui berapa persen tingkat kecocokan rule tersebut dengan pakar, dengan memakai perhitungan sebagai berikut : $\mathrm{P}=\frac{\mathrm{x}}{\mathrm{xi}} \times 100 \%$

Keterangan dari rumus diatas ialah : $\mathrm{P}$ ialah Hasil Presentasi, $X$ ialah Skor pengujian yang sesuai dan $X i$ ialah Jumlah rule yang di uji.

Diketahui : $X=230 \quad X i=230 \quad \mathrm{P}=$ $\mathrm{P}=\frac{230}{230} \times 100 \%=100 \%$

Jadi hasil dari perhitungan diatas dapat diketahui bahwa $\mathrm{P}=100 \%$. Dari nilai pengujian diatas maka dapat diketahui bahwa rule manual yang dibuat oleh pakar sudah sesuai dengan yang ada pada sistem aplikasi yang telah dibuat oleh peneliti.

\subsection{Tampilan Aplikasi}

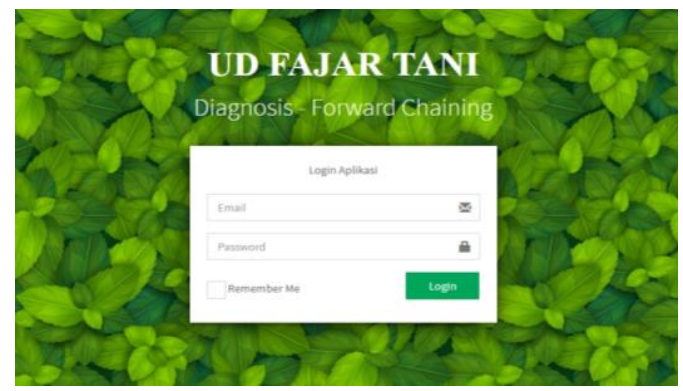

Gambar 4. Halaman login pada aplikasi

Berdasarkan dari ilustrasi 4 diatas ialah tampilan login pada aplikasi, tampilan login merupakan menu pertama sebelum mengakses halaman utama atau dashboard. Halaman ini bertujuan sebagai pembatas antara menu utama di mana pengguna harus memiliki email serta password (akses masuk) untuk membuka halaman utama dan seterusnya. 


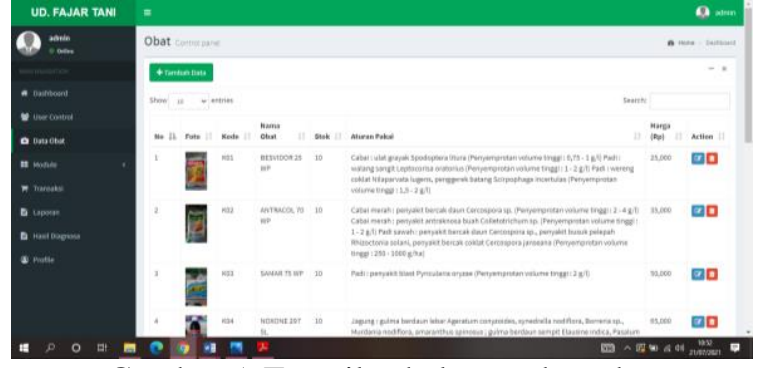

Gambar 5. Tampilan halaman data obat

Selanjutnya berdasarkan dari ilustrasi 5 ini terdapat halaman data obat dimana di dalam menu ini ialah data macam macam obat yang di jual pada UD FAJAR TANI yang dapat diketahui code obat, nama obat, gambar obat, stok obat, aturan pakai obat, serta, harga obat.

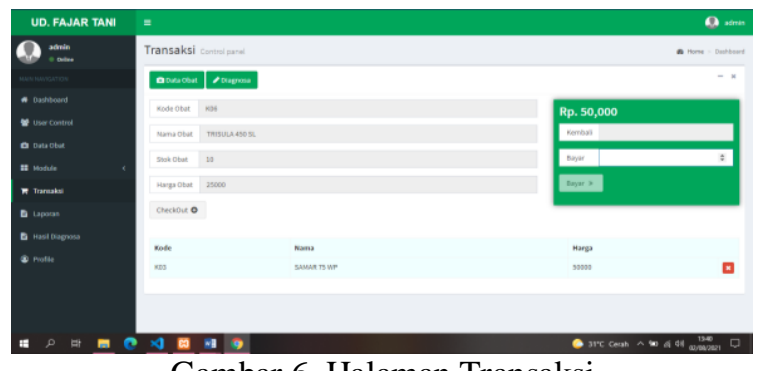

Gambar 6. Halaman Transaksi

Berdasarkan dari ilustrasi 6 diatas ialah halaman transaksi di halaman ini kita bisa melakukan transaksi secara mudah dan cepat terdapat dua icon untuk melakukan transaksi yaitu langsung ke data obat atau ke diagnosa dulu.

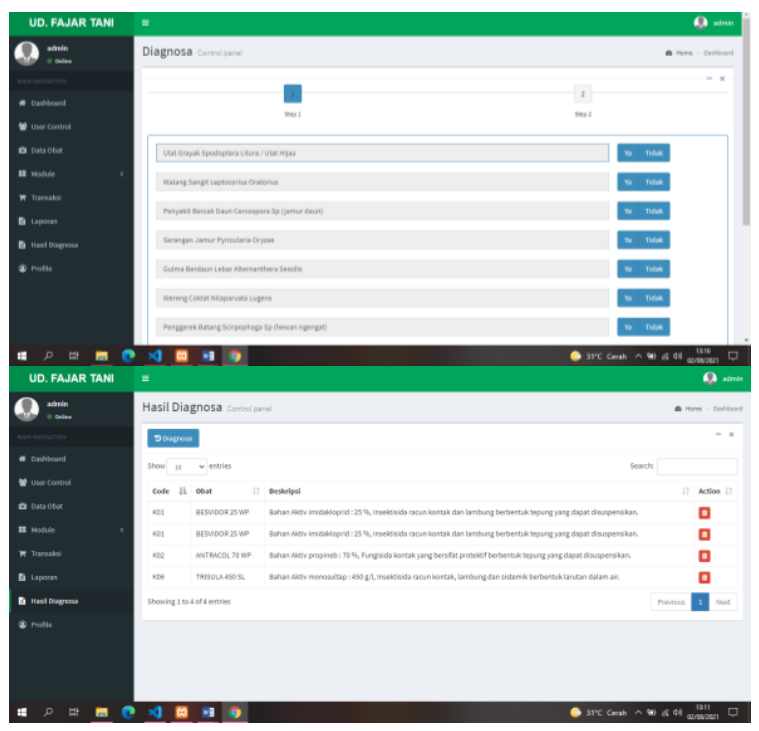

Gambar 7. Halaman Diagnosa

Berdasarkan dari ilustrasi 7 ini ialah menu / halaman yang terdapat metode forward chaining yang merupakan metode yang digunakan oleh peneliti. sesuai dengan aturan forward chaining maka pada menu diagnosa terdapat pilihan YA atau TIDAK dimana pilihan tersebut digunakan untuk menentukan hasil obat atau pestisida yang didapat dari hama atau penyakit yang dipilih. Untuk memilih hama dan penyakit di atas harus sesuai dengan rule yang telah dibuat oleh admin atau pakar dan jika tidak sesuai dengan rule yang dibuat oleh admin atau pakar maka hasil dari hama dan penyakit yang dipilih tidak akan muncul. Setelah selesai mendiagnosa maka dapat kita ketahui hasil diagnosa yang telah kita lakukan dan juga dapat mendiagnosa hasil baru lagi. Berdasarkan dari ilustrasi diatas terdapat 4 hasil diagnosa yang muncul dengan hama / penyakit yang sudah dipilih sebelumnya berdasarkan dari ilustrasi diatas. Dihalaman ini admin / user juga dapat menghapus hasil diagnosa yang sudah dilakukan sebelumnya.

\section{KESIMPULAN DAN SARAN}

\subsection{Kesimpulan}

Berdasarkan pembahasan di atas maka dapat disimpulkan bahwa aplikasi ini dapat digunakan dengan user meminta kepada admin untuk mendaftarkan email dan password terlebih dahulu untuk dapat memakai aplikasi ini. Dalam pengujian fungsional aplikasi tersebut dapat digunakan dengan baik karena mendapat nilai pengujian dari black box sebesar 96,7\%. Dan pengujian rule forward chaining kepada pakar juga mendapatkan nilai yang sangat sesuai sebesar $100 \%$. Serta pengujian kecocokan rule pada aplikasi dengan rule yang dibuat manual kepada 10 sample termasuk pakar juga mendapat nilai yang sangat baik yaitu sebesar $100 \%$ atau bisa dikatakan rule dalam aplikasi sudah sangat sesuai dengan rule yang di tulis manual.

\subsection{Saran}

Berikut ialah saran yang diberikan oleh peneliti tentang penelitian ini.

1. Pengembangan lebih lanjut pada aplikasi ini diharapkan dapat membuat output struk pembelian pada proses transaksi.

2. Diharapkan kedepannya dapat ditambahkan fitur scan harga dari barcode yang ada pada obat.

\section{DAFTAR PUSTAKA}

[1] Suharnawi, R. R. Sani and W. P. Loka, "Sistem Informasi Penjualan Online Berbasis Web pada Toko Sari Tani Tegal," Journal of Information System, pp. 256-264, 2020.

[2] T. Nurmala, A. Rodjak, S. Natasasmita, H. Salim, T. P. Sendjaja, S. Hasani, A. D. Suyono, T. Suganda, T. Simarmata, Y. Yuwariah And S. N. Wiyono, Pengantar Ilmu Pertanian, Yogyakarta: Graha ilmu, 2012.

[3] T. Christy, "Implementasi Sistem Pakar Diagnosa Penyakit Cabe Menggunakan Metode Forward Chaining," Seminar Nasional Royal (SENAR) , p. $353-358,2018$.

[4] U. Rusmawan, Teknik Penulisan Tugas Akir Dan Skripsi Pemrograman, Jakarta: PT Elex Media Komputindo, 2019. 
[5] Y. Purnamasari, T. H. Pudjiantoro And D. Nursantika, "Sistem Penilaian Kinerja Dosen Teladan Menggunakan Metode Simple Multy Attribute Rating Technique (Smart)," Jurnal Teknologi Elektro, Universitas Mercu Buana, p. Vol. 8, 2017.

[6] M. Sukarsa, "Aplikasi Konversi Flowchart Ke Kode Program Bahasa Pemrograman Pl/Sql Mysql," Teknologi Elektro, pp. 44-53, 2019. 